\title{
Article
}

\section{Teacher Dimensions in Technical Higher Education - A Student Perspective}

\author{
Gabriel-Mugurel Dragomir ${ }^{1 *}$, Liliana-Luminița Todorescu ${ }^{2}$ and Anca Greculescu ${ }^{3}$ \\ ${ }^{1}$ Departament of Teaching Training, University Politehnica Timisoara, Piata Victoriei 2, Timisoara \\ 300006, Romania ; E-mail: mugur.dragomir@upt.ro \\ 2 Departament of Teaching Training, University Politehnica Timisoara, Piata Victoriei 2, Timisoara \\ 300006, Romania ; E-mail: liliana.todorescu@upt.ro \\ 3 Department of Communication in Modern Languages, University Politehnica of Bucharest, \\ Splaiul Independentei 313, Bucharest 050099, Romania; E-mail: ancagreculescu@upb.ro
}

* Author to whom correspondence should be addressed; E-mail: mugur.dragomir@upt.ro; Tel.: $+40-723-569-687$

\begin{abstract}
The current paper is based on a survey conducted on 321 engineering students studying at University POLITEHNICA of Bucharest and University POLITEHNICA of Timişoara. The research aims at outlining the profile of the teacher in technical higher education as depicted by engineering students. The results of the study highlight the importance of the student-teacher relationship and of the teacher's roles as evaluator and examiner. Moreover, the test data show significant statistical differences between the real and ideal teacher in technical higher education from a student perspective. Regarding the dimensions of the teacher in technical higher education, based on the statistics, on a 1 to 5 scale, the results show similarities of the two models. For instance, students rank first intelligence and last elitism and competitiveness as teacher attributes.
\end{abstract}

Keywords: teacher, teacher-student relationship, education, teacher dimensions

\section{Introduction}

Didactic planning and management within secondary and pre-tertiary education are teacher-oriented, the teacher being considered its "living tool” (Surdu 2001, p.110). Over the course of time, the teacher has been considered the living tool of educational infrastructure and has faced permanent alterations and restructuring based on different assumptions about education. Subsequently, the teacher has been depicted as apostle, missionary, propedeutic (supplying the knowledge or discipline introductory), maieutic (eliciting new ideas from another, fostering the truth), hermeneutic (concerning interpretation of the truth), manager, consultant, advisor, assessor/evaluator, model, 
partner, agent, learning colleague (for the schoolchild), illuminated guide who descends from his/her pedestal to seek solutions and truths together with the educables. (Jinga et al.1998, p.88; Surdu 2001, p.110).

Over the past quarter of the century, the teacher's mission, roles and functions have constantly and significantly modified. Hence, to meet the economic, social, political and sustainable development (Sterling 2010) requirements of the knowledged-based society and the needs and interests of both schoolchildren and students, there has been a change in their perception of the teacher's characteristics within the pre-tertiary and higher education.

What is more, over the course of the past decades, within tertiary education, there has been a high focus on conducting research likely to outline a profile of the real university teacher as opposed to the ideal one from a student perspective. The aim of these studies is to underline the evolution of the real and ideal teacher's profile in higher education. Thus, there is a constant interest in identifying the characteristics of the ideal teacher, considered important by students and in outlining the dimensions of the real university teacher (performing nowadays in tertiary system). Consequently, the current studies deem fit to highlight the gap between real and ideal in profiling the higher education teacher. (Mannan and Traicoff 1976; Harley, Barasa, Bertram, Mattson and Pillay 2000; Arnon and Reichel 2007; Rusu, Șoitu and Panaite 2011; Haamer, Lepp and Reva 2012; Douna, Kyridis, Zagkos, Ziontaki, and Pandis, 2015; Nartgüna and Özenb 2015).

The purpose of the studies conducted in the field of education is not to turn the real university teacher into an ideal one (since a teacher will never become an ideal, for an ideal is nothing else than the assumption of perfection never found in practice yet, hence, we are always on constant pursuit of it) (Haamer, Lepp, Reva 2012). The aim is to continuously bridge the gap between the real and the ideal teacher, both under ongoing change to comply with sustainable pedagogy and education (Wolff, Sjöblom, HofmanBergholm, Palmberg 2017; Cotton and Winter 2011).

The literature aforementioned as well as studies conducted by Leondari and Kyridis (1999); Kyridis, Dinas, Vlachaiti, Ioannitou, Lambropoulou (2002); Kusto, Afful, Mattingly (2010); Kyridis, Avramidou, Zagkos, Christodoulou, Pavli-Korre (2014); Nurul, Sri Ridhwanah, Nur Hafizah, Chung Ai Wei, Mohd Mu`izzuddin Mohd Nasir, Syahirah Sahari, Shahrill, Mundia (2014); Kseniya Mertins, Veronika Ivanova, Kurkan Nataliya, Ivan Zatonov (2016), Karpouza and Anastassios (2018) focus on the personality traits that depict the ideal university teacher, his/her professional competences (specialized knowledge and a wide range of competences such as: methodological, communication, student-teacher relationship, technical and technological, psychological and social, evaluation and career management, research competences), poise and posture (outfit and 
social behaviour) as well as ethical behaviour. The results show that to students' mind, the ideal university teacher's profile is based on a series of variables regarding gender, age and political beliefs.

The results of these studies show that, students' perceptions about the ideal teacher are highly influenced by a wide range of variables such as age, gender, political beliefs, field of activity and the subject taught, academic and scientific honors and titles. This survey addressed the teacher profile in Romanian technical higher education, from a student perspective by means of:

- $\quad$ teachers as wieved and perceived by students in general;

- teachers viewed and perceived by the society.

The current survey was conducted by means of an isondaje platform on-line questionnaire, and targeted 321 students:

- 176 male students (54.8\%) and 145 female students (45.2\%);

- $207(64.5 \%)$ students studying at University POLITEHNICA of Bucharest and 114 students from University POLITEHNICA of Timişoara (35.5\%);

- $\quad$ respondets' age between 18 and 40.

Q1. What three words would you use to describe teachers (in general)?

Table 1.

\begin{tabular}{clccc}
\hline $\begin{array}{l}\text { No. } \\
\text { Crt. }\end{array}$ & Dimensions of teaching & Frequency & $\begin{array}{c}\text { Percentage } \\
{[\%]}\end{array}$ & $\begin{array}{c}\text { Total added } \\
\text { percentage } \\
{[\%]}\end{array}$ \\
\hline 1 & Teacher-student relationship & 92 & 28.7 & 28.7 \\
2 & Teacher as an evaluator & 68 & 21.2 & 49.9 \\
3 & Professional expertise & 55 & 17.1 & 67 \\
4 & Educational background & 53 & 16.5 & 83.5 \\
5 & Personality traits & 28 & 8.7 & 92.2 \\
6 & Other aspects & 14 & 4.4 & 96.6 \\
7 & Roles of the teacher & 9 & 2.8 & 99.4 \\
8 & Managerial skills & 2 & 0.6 & 100.0 \\
9 & Total & 321 & 100.0 & 617.3 \\
\hline
\end{tabular}




\section{Results}

The results of the survey as shown in Table 1 illustrate the following:

- Students' top choice - teacher-student relationship, 92 respondents (28.7\%), described as: „nice, cool, active, intelligent, wise, respectful, empathetic, attitudinal, committed, dedicated, devoted, engaged, motivated, responsible, responsibility, communicative, disciplined, seriousness, stiffness, authoritative, patient, calm, friendly, kind, pleasant, funny, receptive, inventive, boring, disinterested, communism, superiority, elegance";

- Students' second choice - teacher as an evaluator/assessor, 68 respondents (21.2\%), characterized by: „studying, subject contents, courses, marks/grades, homework, assignments, tests, examination, evaluation, unfair, fair, to sit pass or fail, nervousness, stress etc.)"';

- Students' third choice - teacher's professional expertise, 55 respondents (17.1\%), depicted in terms of: „information, knowledge, culture, capability, professionalism, higher education, capable, smart, new stuff well explained, hardworking, expertise, literate, scholar, future, prosperity, engineer";

- Students' last choices (ranking 7 or 8 ) - various roles of the teacher, 9 respondents $(2.8 \%)$, described as: "teacher, model, friend, advisor, parent, inspirational, guide, mentor"; and managerial skills, 2 respondents $(0.6 \%)$ : „planner, leader".

The teacher-student relationship ranks first in Romanian engineering students' opinions $(28.7 \%)$, since it is regarded as highly important and teaching is by far a relational activity, one with psychological, social and didactic effects between two educational agents: the teacher and the educable (schoolchild or student). What is more, teaching plays a vital role in the quality assurance of the educational process. In prehigher education, the teacher-stident relationship is extremely important (Manyu and Heather 2018), and higher education is just an extension since interpersonal relationships are the basis of coherent and sustainable education.

In higher education, teachers and students alike interact constantly and this interaction counts irrespective of any experiences. Unfortunately, the teacher-student relationship is still pending further research, since only few studies address this topic (Karpouza and Emvalotis 2018).

According to the grid of symbolic interaction (Blumer 1969; Gavreliuc 2002, p.46) applied to the educational system, any social agent engaged in a relationship continuously negotiates the meaning of the situation in which he/she is part of. Hence, students and teachers act in compliance with:

- what they understand of each other;

- the rapport built within educational and social interactions;

- the meanings altered, renewed and passed over within educational interactions. 
The relationship teacher-student builds up in the classroom and it shapes a particular psycho-social, positive and negative environment, and a congenial atmoshpere, respectively. Hence, it positively and negatively influences the teaching and learning quality process which can ensure high educational outcomes and possible low negative consequences at the same time. The literature in the field reveal a direct link between the positive teacher-student relationship and the positive learning environment (Cress 2008), the students' academic performance (Cress 2008; Komarraju, Musulkin, and Bhattacharya 2010; Umbach and Warwrzynski 2005), their high learning motivation (Groves et al. 2015; Komarraju, Musulkin, and Bhattacharya 2010; Schwartz and Holloway 2012; Zepke and Leach 2010), personal learning satisfaction (Calvo, Markauskaite, and Trigwell 2010; Dobransky and Frymier 2004), pride to be affiliated to the higher education institution (Vianden 2015); high professional satisfaction (DocanMorgan 2011; Hagenauer and Volet 2014; Watts and Robertson 2011; Woods 2010).

A positive teacher-student relationship implies commitment, passion, specialized knowledge, trust, respect, openess, authenticity, transparency, availability, responsibility, interest, engagement and equal and fair treatment for every student.

A teacher-student relationship characterized by the teacher's inappropriate behavior, disinterested and unmindful of his/her relationship with the students, unavailable, unapproachable, unfair and biased and who teaches an unfamiliar difficult subject, whose outfit and posture are inappropriate, may a negative impact on the didactic process and on the relationship between the educator and the ones to be educated (Karpouza and Emvalotis, 2018).

By and large, didactic performance is substantially determined by the existing pedagogical relationships. Bad relationships between teachers and students can trigger learning difficulties, students' poor education and training, challenges of classroom management. Consequently, students are aware of this and fairly appreciate the importance of their relationship with the teacher for the learnig process.

The above-mentioned assumptions are also supported by related studies carried out in Romania. Rusu, C.; Șoitu, L.; Panaite, O. (2011, p. 1019) assume that students from Alexandru Ioan Cuza University in Iași, studying at the Humanities and the Faculty of Philosophy and Political Sciences respectively, attach significance to the teacher's ability to create rapport, considered one of the prerequisites for the ideal teacher $(71.42 \%)$. Among other characteristics of the teacher-student relationship mentioned in the research referred to: "...a sympathetic man, a second parent, who communicates with his students, to be a relationship based on trust and genuine interest...", "...a calm man, patient, temperate, gentle, who knows how to approach students, turning them into his own children...". Voicu, O.; Ciolan, L. (2008, p. 7), in their study "The School as it is", argue that "from schoolchildren's point of view, the way a teacher relates to them is 
crucial". "Indulgence, friendliness, fairness or patience are highly sought in a teacher by schoolchildren".

It is worth mentioning that the current research reveals differences in respondents' opinions regarding the teacher-student relationship. Therefore, on one hand, this is perceived as a relaxed, efficient relationship, since it is depicted in terms of „respect, commitment, dedication, engagement, motivation, patience, discipline, seriousness, empathy, calmness, friendliness, understanding, inventivity, courtesy etc." On the other hand, it is perceived as a less positive and efficient relationship and it is characterized by: "communism, boredom, superiority, disinterest, authority etc.".

In line with the latter general opinion, the school, the teacher and the teacher-student relationship are likely to be outdated and old-fashioned, unlikely to overcome the old obsolete methods and attitudes, reluctant to new challenges and changes. It deems necessary to understand students' different opinions, since, over the course of their study years, they meet dozens of teachers with different personalities, different teaching styles and attitudes and different levels of training and education.

Engineering students' second choice - teacher as an evaluator/assessor (21.2\%) reveals the students' threat of evaluation and, especially, of the evaluator as well as the students' misunderstanding of the teacher's role as an evaluator. Traditionally, the teacher is considered the one who criticizes, evaluates and judges unfairly and this role is described in terms of "marks/grades, tests, examination, unfair, to sit pass or fail, nervousness, stress etc".

Currently, the teacher is considered not only an evaluator but also a therapist, capitalizing on the positive aspects of an evaluation and offering objective feedback to the educables. In his/her capacity as a therapist, the evaluation yields its diagnosis role and fosters feasible projects/plans likely to overcome difficulties and ensure educational performance to all agents participating in the educational process. [Jinga, I.; Istrate, E (coord.) (1998)].

Ranking third in students' views, by $17.1 \%$, the teacher's professional expertise means intellectual authority, possession of specialized knowledge, swapping of knowhow with students and development of specialized competences necessary for students' future career. What is more, this opinion is expressed in terms of "information, knowledge, expertise, culture, capability, professionalism, literate, scholar, capable, smart, new things well explained, hardworking, experience, future, prosperity, engineer etc".

According to Rusu, C.; Șoitu, L.; Panaite, O. (2011, p. 1019), teachers' fair assessment ranks second in students' opinions by $66.23 \%$, and third comes "knowledge of the 
subject" by $58.44 \%$. The fourth place as importance in students'views is the teacher as a "facilitator of students' intellectual development" by $55.84 \%$.

The last ranks in the current research belong to the roles of the teacher $(2.4 \%)$ and managerial skills (0.6 \%), labelled as "teacher, model, advisor, friend, parent, inspirational, guide, planner, mentor". This explains the existence of an environment in which the teacher still plays traditional roles and acts less as a planner, guide or facilitator. At the same time, it becomes worth mentioning the new modern roles performed by the teacher in line with nowadays educational dynamics: advisor, guide, inspirational, facilitator of learning, planner and organizer. Hence, the focus is gradually shifted from knowledge-based product to knowledge-based process, the teacher attaching greater importance to the students' learning needs, motivation, guidance and disregarding the delivery of prefabricated knowledge.

All in all, the labels used by students in the present study regarding the university teacher and the corresponding features envisioned by the target group in the research conducted by Rusu, C.; S,oitu, L.; Panaite, O. (2011), concerning the ideal university teacher are similar. Thus, students from different areas and universities or specializations display similar perception and interaction patterns with the teacher.

Q2. How do you think teachers are perceived in Romania?

Table 2.

\begin{tabular}{ccc}
\hline University & $\begin{array}{c}\text { Students'opinions on } \\
\text { teachers } \\
\text { (statistical mean) }\end{array}$ & $\begin{array}{c}\text { Society opinion on } \\
\text { teachers } \\
\text { (statistical mean) }\end{array}$ \\
\hline $\begin{array}{c}\text { University Politehnica of } \\
\text { Bucharest }\end{array}$ & 3.64 & 2.86 \\
$\begin{array}{c}\text { University Politehnica of } \\
\text { Timişoara }\end{array}$ & 4.02 & 3.01 \\
Representative sample & 3.78 & 2.91 \\
\hline
\end{tabular}

Taking into consideration students' answers to the above question, it deems fit to notice their high appreciation of teachers provided the direct contact with them (also shown from the statistical means in Table 2), whereas the rest of society reveals unfair low appreciation of teachers. The difference is statistically significant as proved by the test $\mathrm{t}=75,360(\mathrm{p}<0,01)$.

Therefore, direct contact and relationship that students have with the educational system and teachers bring about students'empathy to their trainers, thus, appreciating their effort and commitment likely to assist them in becoming specialists in various domanins. On the contrary, those who have lost contact with education and teachers will 
no longer consider this profession important and, unfortunately, they become unmindful of the importance of teaching and teachers considered the basis of all professions and jobs. Moreover, it is worth mentioning that further development of society relies heavily on teachers and their dedication.

Q3. To what extent do you think the following attributes fit to the real/ideal teacher's profile?

\section{Table 3.}

\begin{tabular}{clccc}
\hline No.crt. Attributes & Real & Ideal & Comparison \\
\hline 1 & 3.1 Flexible & 3.32 & 4.12 & $\mathrm{t}=58.41 ; \mathrm{p}<0.01$ \\
2 & 3.2 Efficient & 3.59 & 4.36 & $\mathrm{t}=64.73 ; \mathrm{p}<0.01$ \\
3 & 3.3 Logic & 3.69 & 4.37 & $\mathrm{t}=60.33 ; \mathrm{p}<0.01$ \\
4 & 3.4 Sincere & 3.75 & 4.21 & $\mathrm{t}=58.10 ; \mathrm{p}<0.01$ \\
5 & 3.5 Tolerant & 3.23 & 4.02 & $\mathrm{t}=49.41 ; \mathrm{p}<0.01$ \\
6 & 3.6 Credible & 3.66 & 4.24 & $\mathrm{t}=61.41 ; \mathrm{p}<0.01$ \\
7 & 3.7 Modern & 3.39 & 4.22 & $\mathrm{t}=53.85 ; \mathrm{p}<0.01$ \\
8 & 3.8 Transparency in actions & 3.36 & 3.93 & $\mathrm{t}=57.91 ; \mathrm{p}<0.01$ \\
9 & 3.9 Responsible & 4.07 & 4.44 & $\mathrm{t}=76.03 ; \mathrm{p}<0.01$ \\
10 & 3.10 Funny & 3.49 & 4.17 & $\mathrm{t}=55.12 ; \mathrm{p}<0.01$ \\
11 & 3.11 Performant & 3.76 & 4.33 & $\mathrm{t}=64.92 ; \mathrm{p}<0.01$ \\
12 & 3.12 Competitive & 3.19 & 3.53 & $\mathrm{t}=49.91 ; \mathrm{p}<0.01$ \\
13 & 3.13 Distinguished & 3.39 & 3.93 & $\mathrm{t}=58.67 ; \mathrm{p}<0.01$ \\
14 & 3.14 Unique & 3.39 & 3.97 & $\mathrm{t}=46.99 ; \mathrm{p}<0.01$ \\
15 & 3.15 Trustworthy & 3.91 & 4.45 & $\mathrm{t}=68.18 ; \mathrm{p}<0.01$ \\
16 & 3.16 Approachable & 3.16 & 4.00 & $\mathrm{t}=45.88 ; \mathrm{p}<0.01$ \\
17 & 3.17 Creative & 3.45 & 4.27 & $\mathrm{t}=55.96 ; \mathrm{p}<0.01$ \\
18 & 3.18 Elitist & 3.21 & 3.59 & $\mathrm{t}=53.54 ; \mathrm{p}<0.01$ \\
19 & 3.19 Intelligent & 4.35 & 4.61 & $\mathrm{t}=88.70 ; \mathrm{p}<0.01$ \\
20 & 3.20 Good communicator & 3.80 & 4.57 & $\mathrm{t}=62.61 ; \mathrm{p}<0.01$ \\
21 & 3.21 Patient & 3.42 & 4.25 & $\mathrm{t}=54.79 ; \mathrm{p}<0.01$ \\
22 & 3.22 Passionate & 3.87 & 4.44 & $\mathrm{t}=69.40 ; \mathrm{p}<0.01$ \\
23 & 3.23 Good organizer & 3.63 & 4.29 & $\mathrm{t}=65.05 ; \mathrm{p}<0.01$ \\
24 & 3.24 Punctual & 3.94 & 4.22 & $\mathrm{t}=64.84 ; \mathrm{p}<0.01$ \\
\hline & & &
\end{tabular}


There are statistically significant differences for all attributes listed in Table 3, regarding the profile of the real and the ideal teacher in technical higher education from a student perspective. On one hand, the results show the real is not tentamount to ideal, since the ideal does not exist in practice, it is more a target to be achieved. On the other hand, there is always room for teaching development inasmuch as we are well aware of the students' preferences and opinions about the characteristics of their desired teacher or trainer. Therefore, there is a constant need to bridge the gap between real and ideal, provided a clear profile of the teacher as outlined by students. Therefore, the teacher's future bahaviour is likely to change to fit properly into the educational and instructional processes. Moreover, this is likely to bring about alterations of the curricula for future teachers' psychopedagogical training.

To highlight a few essential teacher dimensions regarding the real and ideal model in higher education, we have observed the results of the research as illustrated in Table 4 below. In this sense, one observation is that on a 1 to 5 marking scale, intelligence ranks first for both teacher models, real (4.35) and ideal (4.61). More than anything, for students, intelligence is crucial when it comes to their teachers. And this is because teaching, as a profession, makes the teacher face challenges, deal with diverse and unexpected situations in the classroom, never encountered before. Hence, intelligence, as a superior form of optimal and efficient adaptation to new difficult puzzling situations, by means of restructuring of previous experiential data, proves a prerequisite for any teacher likely to overcome this kind of predicament.

Second in the ranking comes responsible/ responsibility (4.07), proving students' perceptions of the real teacher as a responsible person who shows respect for the profession and assumes consequent responsibilities and duties. Punctual ranks third (3.94), which explains students's perceptions of the higher education teacher regarded as a person mindful of efficient time keeping in the classroom. Regarding didactics, punctuality is considered a form of respect for the educables and their efficient training alike. Ranking fourth, the attribute of trustworthy (3.91) underlines the importance for keeping one's promise and taking the teacher's words for granted.

As far as the ideal teacher is concerned, the following attributes rank second and third: good communicator (4.57) and trustworthy/a person of his/her word (4.45). Thus, students highly appreciate a teacher who is a good communicator, who can efficiently transmit specialized information to make himself/herself clear to the students, who is able to create rapport with them and create a congenial positive interpersonal atmosphere likely to stimulate and support every student in their learning process. To students' mind, the ideal academic teacher can understand their needs, behaviour, a trustworthy person, of his/her word, never changing mind or ideas, demands or expectations, nor mood. Responsible, as an attribute of the ideal academic teacher, ranks fourth (4.44). 
Passionate is next in ranking, on the fifth position, the real teacher model (3.87) and the ideal (4.44) respectively. In fact, in this case, the real is tentamount to ideal in the sense that students would prefer a passionate academic teacher both in practice and theory. Passion implies a calling for this profession, vocation, dedication, hard work and commitment. It is worth mentioning the positive aspect of this students' observation.

In the aftermath of the afore-mentioned, the first five positions of the ranking concerning the attributes assigned to the academic teachers, both profiles of the real and ideal teacher share 4 common characteristics (intelligent, responsible, trustworthy, pasionate), two of them being placed on the same position in both models (intelligent first rank and passionate - fifth rank). Consequently, there is a huge similarity between the students' expectations from a higher education teacher and the way they perceive their real teachers, surprisingly and encouraging at the same time.

The research conducted by Kseniya Mertins, Veronika Ivanova, Kurkan Nataliya, Ivan Zatonov (2016, p. 4) in the field of the ideal academic teacher, confirms the fact that "the most appropriate adjectives, assigned to an ideal teacher by students were: conscious and intelligent, kind, responsible, interesting, skilled, sensible, sociable, wise, considerate, charismatic. Among the professional characteristics, the following adjectives were chosen: fair, experienced, determined, high skilled, good at her/his subject, tough, engaged, creative."

Among the last ranking adjectives are elitist (3. 21), competitive (3. 19) and approachable (3.16). This fact illustrates that students do not consider the higher education teacher an elitist, a distinguished superior and competitive person, in the pursuit of professional affirmation. Nor is the academic teacher perceived as approachable. Hence, even if the teacher is intelligent, responsible and punctual (the first three ranked attributes), they are not available off-duty and ready to provide students with additional information, nor likely to offer learning support for their students.

Regarding the adjectives assigned to the ideal academic teacher, the last three ranking positions are occupied by transparency in actions (3.93), elitist (3.59) and competitive (3.53). We can assume that a transparent teacher in actions is not important for students. Furthermore, for them, it does not matter whether their teacher is an elitist, cultivated, superior or prone to self-sufficiency or competitive. 
We notice that 2 adjectives (elitist and competitive) are common for both the real and ideal models, hence such a teacher is neither wanted nor does he/she exist.

Table 4 .

\begin{tabular}{|c|c|c|c|c|}
\hline & Attributes & Real & Attributes & Ideal \\
\hline 1 & 3.19 Intelligent & 4.35 & 3.19 Intelligent & 4.61 \\
\hline 2 & 3.9 Responsible & 4.07 & $\begin{array}{l}3.20 \text { Good } \\
\text { communicator }\end{array}$ & 4.57 \\
\hline 3 & 3.24 Punctual & 3.94 & $\begin{array}{l}3.15 \text { Trustworthy/of } \\
\text { their word }\end{array}$ & 4.45 \\
\hline 4 & $\begin{array}{l}3.15 \text { Trustworthy/of their } \\
\text { word }\end{array}$ & 3.91 & 3.9 Responsible & 4.44 \\
\hline 5 & 3.22 Passionate & 3.87 & 3.22 Passionate & 4.44 \\
\hline 6 & 3.20 Good communicator & 3.8 & 3.3 Logical & 4.37 \\
\hline 7 & 3.11 Performant & 3.76 & 3.2 Efficient & 4.36 \\
\hline 8 & 3.4 Sincere & 3.75 & 3.11 Performant & 4.33 \\
\hline 9 & 3.3 Logical & 3.69 & 3.23 Good organizer & 4.29 \\
\hline 10 & 3.6 Credible & 3.66 & 3.17 Creative & 4.27 \\
\hline 11 & 3.23 Good organizer & 3.63 & 3.21 Patient & 4.25 \\
\hline 12 & 3.2 Efficient & 3.59 & 3.6 Credible & 4.24 \\
\hline 13 & 3.10 Funny & 3.49 & 3.24 Punctual & 4.22 \\
\hline 14 & 3.17 Creative & 3.45 & 3.7 Modern & 4.22 \\
\hline 15 & 3.21 Patient & 3.42 & 3.4 Sincere & 4.21 \\
\hline 16 & 3.7 Modern & 3.39 & 3.10 Funny & 4.17 \\
\hline 17 & 3.13 Distinguished & 3.39 & 3.1 Flexible & 4.12 \\
\hline 18 & 3.14 Unique & 3.39 & 3.5 Tolerant & 4.02 \\
\hline 19 & 3.8 Transparent in actions & 3.36 & 3.16 Approachable & 4 \\
\hline 20 & 3.1 Flexible & 3.32 & 3.14 Unique & 3.97 \\
\hline 21 & 3.5 Tolerant & 3.23 & 3.13 Distinguished & 3.93 \\
\hline 22 & 3.18 Elitist & 3.21 & $\begin{array}{l}3.8 \text { Transparent in } \\
\text { actions }\end{array}$ & 3.93 \\
\hline 23 & 3.12 Competitive & 3.19 & 3.18 Elitist & 3.59 \\
\hline 24 & 3.16 Approachable & 3.16 & 3.12 Competitive & 3.53 \\
\hline
\end{tabular}


Q4. To what extent do you agree with the following assumptions about the real higher education teacher?

Table 5.

\begin{tabular}{lll}
\hline $\begin{array}{l}\text { No. } \\
\text { crt. }\end{array}$ & Assumptions & $\begin{array}{l}\text { Statistical } \\
\text { mean }\end{array}$ \\
\hline 1 & $\begin{array}{l}\text { Teachers successfully overcome didactic and professional challenges } \\
\text { in educational and instructional activity }\end{array}$ & 3.6 \\
2 & Teachers encourage students to speak their mind freely & 3.57 \\
3 & Teachers are concerned about quality assurance in teaching & 3.55 \\
4 & Teachers do not make vulgar remarks to students & 3.43 \\
5 & Teachers show enthusiasm for the taught subject & 3.4 \\
6 & Teachers provide students with feedback on evaluation & 3.3 \\
7 & Teachers use interactive teaching methods & 3.24 \\
8 & Teachers put theory into practice in teaching & 3.22 \\
9 & Teachers lack methodology and structure in teaching & 2.63 \\
10 & Teachers do not objectively evaluate students & 2.61 \\
11 & Teachers are arrogant and treat students condescendingly & 2.6 \\
12 & Teachers are unavailable off-duty & 2.56 \\
13 & Teachers are not open to communication with students & 2.33 \\
14 & Teachers lack updated specialized knowledge & 2.26 \\
15 & Teachers miss appointments with students & Teachers make sexist or misogynistic remarks to female students \\
\hline & & 1.93 \\
\hline
\end{tabular}


The new correlation of factors (Rotation Matrix)

Table 6.

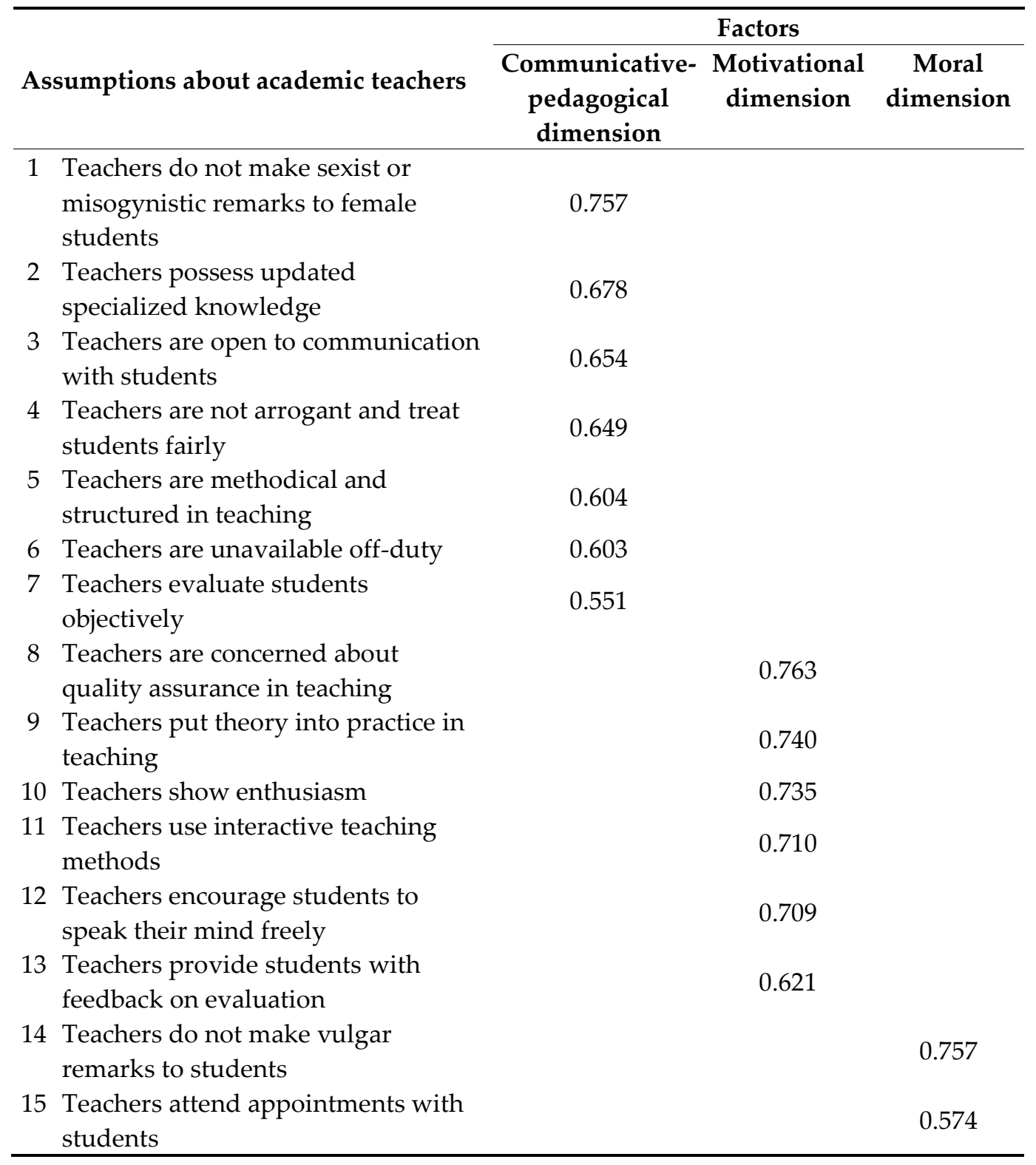

The items listed in Q4 were analyzed according to the correlations of all the 16 selected assumptions. Three factors with values higher or equal to 1.00 were selected. The rotation of factors led to the structure provided in the previous table. The first factor 
counts for $21.66 \%$ of the variant, the second for $21.61 \%$ and the third for $7.36 \%$ of the variant. Summing up, the four factors count for $50.65 \%$ of the variant.

Factor 1 (Communicative-pedagogical dimension) correlates with the initial variables as follows: teachers do not make sexist or misogynistic remarks to female students (0.757); Teachers possess updated specialized knowledge (0.678); Teachers are open to communication with students (0.654); Teachers are not arrogant and treat students fairly (0.649); Teachers are methodical and structured in teaching (0.604); Teachers are available off-duty (0.603); Teachers evaluate students objectively (0.551).

Factor 2 (Motivational dimension) correlates with the initial variables as follows: Teachers are concerned about quality assurance in teaching (0.763); Teachers put theory into practice in teaching (0.740); Teachers show enthusiasm (0.735); Teachers use interactive teaching methods (0.710); Teachers encourage students to speak their mind freely (0.709); Teachers provide students with feedback on evaluation (0.621).

Factor 3 (Moral dimension) correlates with the initial variables as follows: Teachers do not make vulgar remarks to students (0.757); Teachers attend appointments with students (0.574).

Q5. To what extent do you agree with the following assumptions about the real higher education teacher?

Table 7.

No.

crt.

Assumptions

Statistical

mean

1 Teachers successfully overcome didactic and professional challenges in educational and instructional activity

2 Teachers encourage students to speak their mind freely

3 Teachers are concerned about quality assurance in teaching

4 Teachers do not make vulgar remarks to students

5 Teachers show enthusiasm for the taught subject

6 Teachers are methodical and structured in teaching

7 Teachers provide students with feedback on evaluation

8 Teachers use interactive teaching methods

9 Teachers put theory into practice in teaching

10 Teachers do not make sexist or misogynistic remarks to female students

11 Teachers attend appointments with students

12 Teachers possess updated specialized knowledge

13 Teachers are open to communication with students 
14 Teachers are available off-duty

15 Teachers are not arrogant and treat students fairly

16 Teachers evaluate students objectively

The profile of the real academic teacher has been outlined by means of a range of assumptions regarding the didactic activity, the teacher-student relationship extra school hours and students' evaluation methodology.

This has led to a hierarchy of answers ranked on a 1 to 5 scale, in a decreasing order from 3.6 to 2.39 . The average is set to range between 2.74 and 3.24 , namely around 3 .

The top ranking addresses the following assumptions:

- $\quad$ Teachers successfully overcome didactic and professional challenges in educational and instructional activity (3.6);

- $\quad$ Teachers encourage students to speak their mind freely (3.57);

- $\quad$ Teachers are concerned about quality assurance in teaching (3.55);

- $\quad$ Teachers do not make vulgar remarks to students (3.43);

- Teachers show enthusiasm for the taught subject (3.4);

- Teachers are methodical and structured in teaching (3.37);

- $\quad$ Teachers provide students with feedback on evaluation (3.3).

These research findings reveal students' appreciation for their teachers' openness, the quality of the subjects taught and their feedback on evaluation. Moreover, there is positive appreciation for the other aspects mentioned, to be investigated in further research: communication with students during breaks or off-duty and extra school hours, arrogant attitude towards students and lack of objective evaluation. 
Q6. To what extent do you agree with the following rights and obligations of teachers and students alike?

Table 8.

\begin{tabular}{|c|c|c|}
\hline $\begin{array}{l}\text { No. } \\
\text { crt. }\end{array}$ & Rights and obligations of teachers and students & $\begin{array}{l}\text { Statistical } \\
\text { mean }\end{array}$ \\
\hline 1 & Students are entitled to an optimum learning environment & 4.48 \\
\hline 2 & Teachers are entitled to use clear, calm and firm voice and eye contact & 4.4 \\
\hline 3 & $\begin{array}{l}\text { Students are entitled to expect appropriate behaviour from their } \\
\text { teachers }\end{array}$ & 4.37 \\
\hline 4 & $\begin{array}{l}\text { Teachers are entitled to expect appropriate behaviour from their } \\
\text { students }\end{array}$ & 4.32 \\
\hline 5 & $\begin{array}{l}\text { Students are entitled to individual attention from their teachers - } \\
\text { salutations, small talk, encouragement, understanding, smiles, } \\
\text { friendly eye-contact etc. }\end{array}$ & 4.19 \\
\hline 6 & $\begin{array}{l}\text { Teachers are entitled to influence students' behaviour without } \\
\text { threatening or shouting }\end{array}$ & 4.03 \\
\hline 7 & $\begin{array}{l}\text { Teachers are entitled to use gestures likely to support oral } \\
\text { communication }\end{array}$ & 4.02 \\
\hline 8 & $\begin{array}{l}\text { Efficient teachers will set high expectations and standards and assist } \\
\text { students in meeting }\end{array}$ & 3.85 \\
\hline 9 & $\begin{array}{l}\text { Teachers are entitled to set and pursue expectations from students' } \\
\text { behaviour }\end{array}$ & 3.74 \\
\hline 10 & $\begin{array}{l}\text { Students are entitled to special observations - from comments on } \\
\text { papers to graduation theses. }\end{array}$ & 3.69 \\
\hline
\end{tabular}

Another objective of the current study is to sustain Marlene and Lee Canter's suggestion that teachers should display positive attitude. Therefore, the questionnaire also addresses some rights and obligations of teachers and students in line with Canters' proposal. (Stan, 2006: 58-78):

Teachers' fundamental rights:

- $\quad$ to ensure an optimum learning environment;

- $\quad$ to expect appropriate behaviour from their students;

- $\quad$ to expect appropriate support from parents and school administration if need be. 


\section{Students' fundamental rights:}

- $\quad$ to have a teacher likely to assist them in developing and prevent them from selfdestruction due to inappropriate behaviour;

- $\quad$ to receive support from the teacher to acquire appropriate behavior;

- to adopt a certain type of behaviour provided previous awareness of their choice and subsequent consequences.

The rights of both academic parties (teachers and students) as formulated by the Canters are validated as follows:

\section{Teachers}

Table 9.

\begin{tabular}{clc}
\hline $\begin{array}{c}\text { No. } \\
\text { crt. }\end{array}$ & Teachers' rights & $\begin{array}{c}\text { Statistical } \\
\text { mean }\end{array}$ \\
\hline 1 & Teachers are entitled to use clear, calm and firm voice and eye contact & 4.4 \\
2 & $\begin{array}{l}\text { Teachers are entitled to expect appropriate behaviour from their } \\
\text { students }\end{array}$ & 4.32 \\
3 & $\begin{array}{l}\text { Teachers are entitled to influence students' behaviour without } \\
\text { threatening or shouting }\end{array}$ & 4.03 \\
4 & $\begin{array}{l}\text { Teachers use gestures to support verbal assertions } \\
5\end{array}$ & $\begin{array}{l}\text { Teachers are entitled to use gestures likely to support oral } \\
\text { communication }\end{array}$ \\
6 & $\begin{array}{l}\text { Teachers are entitled to set and pursue expectations from students' } \\
\text { behaviour }\end{array}$ & 3.02 \\
\hline
\end{tabular}

\section{Students}

Table 10.

\begin{tabular}{clc}
\hline $\begin{array}{l}\text { No. } \\
\text { crt. }\end{array}$ & \multicolumn{1}{c}{ Students' rights } & $\begin{array}{c}\text { Statistical } \\
\text { mean }\end{array}$ \\
\hline 1 & $\begin{array}{l}\text { Students are entitled to an optimum learning environment } \\
2\end{array}$ & $\begin{array}{l}\text { Students are entitled to expect appropriate behaviour from their } \\
\text { teachers }\end{array}$ \\
3 & $\begin{array}{l}\text { Students are entitled to individual attention from their teachers - } \\
\text { salutations, small talk, encouragement, understanding, smiles, } \\
\text { friendly eye-contact etc. }\end{array}$ & 4.37 \\
&
\end{tabular}




\begin{tabular}{clc}
\hline $\begin{array}{l}\text { No. } \\
\text { crt. }\end{array}$ & \multicolumn{1}{c}{ Students' ${ }^{\prime}$ rights } & $\begin{array}{c}\text { Statistical } \\
\text { mean }\end{array}$ \\
\hline 1 & Students are entitled to an optimum learning environment & 4.48 \\
2 & $\begin{array}{l}\text { Students are entitled to expect appropriate behaviour from their } \\
\text { teachers }\end{array}$ & 4.37 \\
3 & $\begin{array}{l}\text { Students are entitled to individual attention from their teachers - } \\
\text { salutations, small talk, encouragement, understanding, smiles, } \\
\text { friendly eye-contact etc. }\end{array}$ & 4.19 \\
4 & $\begin{array}{l}\text { Students are entitled to special observations - from comments on } \\
\text { papers to graduation theses. }\end{array}$ & 3.69 \\
\hline
\end{tabular}

\section{Conclusions}

The current study addresses the profile of the teacher in technical higher education in Romania and it was conducted at University POLITEHNICA of Bucharest and University POLITEHNICA of Timişoara. The target group consisted of 321 interviewees, 176 male students and 145 female students. The survey was based on an on-line questionnaire. The results of the research illustrate the following:

- $\quad$ Students rank first the teacher-student relationship (28.7\%), thus explaining their rapport based on continuous interaction between the two educational agents. To students' mind, the relationship between the trainer and the trainee, between the master and the apprentice is more important than the knowledge provided;

- The teacher as an evaluator ranks second (21.2\%) and argues for the stress students experience during examination periods. Moreover, it underlines the evaluator's authority bound to certify the competences of the one who studies and who wishes to obtain a "trip ticket", that is the diploma likely to ensure confidence in your own capacity and career opportunities;

- The teacher as knowledge provider ranks third. The teacher is depicted in terms of know-how, expertise, culture and considered a reliable and worthy icon for students;

- $\quad$ The students who are directly engaged in the educational and instructional process and in their relationship with the teachers appreciate them more than the ones who have lost contact with the teachers;

- The ranking of attributes assigned to academic teachers emphasizes intelligence, in case of the real teacher the statistical mean is (4.35) and for the ideal one (4.61). Furthermore, the last three positions tackle adjectives such as elitist and competitive, hence students will look for intelligent higher education teachers, capable to face 
professional challenges. Nevertheless, they should not be bound to elitism, perfection, self-sufficiency nor competitivness or on a constant pursue of selfaffirmation.

- The current research is in line with the model proposed by Marlene and Lee Canter who advise teachers to take on a positive attitude in education, thus observing the fundamental rights of teachers and students alike.

- The challenges of the current study are the limited sample of the target group and the application of the questionnaire to both schoolchildren and engineering students, at the same time.

\section{References}

(Arnon and Reichel [2007]) Arnon Sara, and Reichel Nirit. 2007. Who is the ideal teacher? Am I? Similarity and difference in perception of students of education regarding the qualities of a good teacher and of their own qualities as teachers. Teachers and Teaching: 441-464. Vol. 13, Issue 5. doi.org/10.1080/13540600701561653.

(Blumer [1969]) Blumer Herbert. 1969. Symbolic interactionism. Perspective and method. Englewood: Prenticew Hall.

(Calvo, Markauskaite, and Trigwell [2010]) Calvo Rafael, Markauskaite Lin, and Trigwell Keith. 2010. Factors Affecting Students' Experiences and Satisfaction about Teaching Quality in Engineering. Australasian Journal of Engineering Education. Vol. 16 (2): 139-148. doi.org/10.1080/22054952.2010.11464049.

(Cotton, and Winter [2011]) Cotton Debby, and Winter Jennie. 2011. Making the hidden curriculum visible: sustainability literacy in higher education. Enviromental Education Research: 783-796. Volume 18, 2012 - Issue 6. doi.org/10.1080/13504622.2012.670207.

(Cress [2008]) Cress Christine M. 2008. Creating inclusive learning communities: the role of studentfaculty relationships in mitigating negative campus climate. Learning Inquiry: 95-111. Vol.2. Issue 2. ISSN: 1558-2973 (Print) 1558-2981(Online). doi:10.1007/s11519-008-0028-2.

https://link.springer.com/article/10.1007/s11519-008-0028-2.

(Dobransky, and Frymier [2004]) Dobransky Nicole D., and Frymier Ann Bainbridge. 2004. Developing teacher-student relationships through out of class communication. Communication Quarterly: 211-223. Vol. 52. Issue 3. doi.org/10.1080/01463370409370193.

(Docan-Morgan [2011]) Docan-Morgan Tony. 2011. „Everything Changed”: Relational Turning Point Events in College Teacher-Student Relationships from Teachers' Perspectives." Communication Education : 20-50. Vol. 60 . Issue 1. doi.org/10.1080/03634523.2010.497223.

(Douna, Kyridis, Zagkos, Ziontaki and Pandis [2015]) Douna Poulcheria, Kyridis Argyris, Zagkos Christos, Ziontaki Zoi, and Pandis Prokopis. 2015. The Ideal University Teacher according to the Views of Greek Students. International Journal of Higher Education. Vol. 4, No. 2. ISSN 19276044 (Print) ISSN 1927-6052 (Online). doi.org/10.5430/ijhe.v4n2p145.

(Gavreliuc [2002]) Gavreliuc Alin. 2002. O călătorie alături de „celălalt”. Timişoara: Editura Universităţii de Vest. 
(Groves, Sellars, Smith and Barber [2015]) Groves Mark, Sellars Christopher, Smith Julian, and Barber Alison. 2015. Factors Affecting Student Engagement: A Case Study Examining Two Cohorts of Students Attending A Post-1992 University in The United Kingdom. International Journal of Higher Education: 27-37. Vol 4. Nr. 2. doi.org/10.5430/ijhe.v4n2p27

(Haamer, Lepp and Reva [2012]) Haamer Anu, Lepp Liina, and Reva Elina. 2012. The Dynamics Of Professional Identity Of University Teachers: Reflecting On The Ideal University Teacher. Studies for the Learning Society: 110-120. Vol 2 Issue 2-3. ISSN 1736-710. doi.org/10.2478/v10240-0120010-5.

(Hagenauer and Volet [2014]) Hagenauer Gerda, and Volet Simone. 2014. I Don't Think I Could, You Know, Just Teach without Any Emotion': Exploring the Nature and Origin of University Teachers' Emotions. Research Papers in Education : 240-262. Vol. 29. Issue 2. doi.org/10.1080/02671522.2012.754929.

(Harley, Barasa, Bertram, Mattson and Pillay [2000]) Harley Ken, Barasa Fred, Bertram Carol, Mattson Elizabeth, and Pillay Shervani. 2000. The real and the ideal: teacher roles and competences in South African policy and practice. International Journal of Educational Development: 287-304. Vol. 20. Issue 4. doi.org/10.1016/S0738-0593(99)00079-6

(Karpouza and Emvalotis [2018]) Karpouza Eleni, and Emvalotis Anastassios. 2018. Exploring the teacher-student relationship in graduate education: a constructivist grounded theory. Teaching in higher education. Journal homepage: http://srhe.tandfonline.com/loi/cthe20.doi.org/ 10.1080/13562517.2018.1468319. ISSN: 1356-2517 (Print) 1470-1294 (Online).

(Komarraju, Musulkin and Bhattacharya [2010]) Komarraju Meera, Musulkin Sergey, and Bhattacharya Gargi. 2010. Role of Student-Faculty Interactions in Developing College Students' Academic Self-Concept, Motivation, and Achievement. Journal of College Student Development: 332-342. Vol 51. Nr.3 doi:10.1353/csd.0.0137.

(Kusto, Afful and Mattingly [2010]) Kusto Accalia R., Afful Stephanie E., and Mattingly Brent A. 2010. Students' Perceptions of and Preferences for Professors. The New School Psychology Bulletin : 47-55. Vol. 8, No.1, Print ISSN: 1931-793X; Online ISSN: 1931-7948

(Kyridis, Dinas, Vlachaiti, Ioannitou, and Lambropoulou [2002]) Kyridis Argyris, Dinas Konstantinos, Vlachaiti V., Ioannitou E., and Lambropoulou. 2002. Undergraduate students describe the ideal university teacher. Contemporary Education, 122, pp. 78-87.

(Kyridis, Avramidou, Zagkos, Christodoulou and Pavli-Korre [2014]) Kyridis Argyris, Avramidou Maria, Zagkos Christos, Christodoulou Anastasia, and Pavli-Korre Maria. 2014. Who is the ideal teacher? Greek pre-service teachers express their views about the characteristics of the-perfect teacher. Journal for Educators, Teachers and Trainers:143 - 159. Vol. 5(2). ISSN 1989 - 9572. http://www.ugr.es/ jett/index.php.

(Jinga and Istrate [1998]) Jinga Ioan and Istrate Elena. 1998. Manual de Pedagogie. București: Editura All, p. 88.

(Leondari and Kyridis [1999]) Leondari Angeliki and Kyridis Argyris. 1999. Who is the good teacher? Let the students describe him. Nea Paedia 92:159-181.

(Mannan and Traicoff [1976]) Manna, Golam, and Traicoff Ellen M. 1976. Evaluation of an Ideal University Teacher. Improving College and University Teaching: 98-101. Vol. 24. Issue 2. doi.org/10.1080/00193089.1976.9927308. 
(Manyu and Stone [2018]) Manyu Li, and Stone Heather Nicole. 2018. A Social Network Analysis of the Impact of a Teacher and Student Community on Academic Motivation in a Science Classroom. Societies 8(3), 68. doi.org/10.3390/soc8030068.

(Nartgüna and Sezghin [2015]) Nartgüna Şenay, and Sezghin Özenb Rașit. 2015. Investigating pedagogical formation students' opinions about ideal teacher, teaching profession, curriculum, responsibility, public personnel selection examination (ppse) and employment: A metaphor study. Procedia - Social and Behavioral Sciences : $2674-2683$. Vol 174. doi.org/10.1016/j.sbspro.2015.01.951.

(Nurul, Sri Ridhwanah, Nur, Chung, Ivanova, Mohd, Ummi, Masitah and Lawrence [2014]) Nurul Azureen Omar, Sri Ridhwanah Matarsat, Nur Hafizah Azmin, Chung Ai Wei, Ivanova Veronika, Mohd Mu`izzuddin Mohd Nasir, Ummi Kalthum Syahirah Sahari, Masitah Shahrill, and Lawrence Mundia. 2014. The Ideal Psychology Teacher: Qualitative Analysis of Views from Brunei GCE A-Level Students and Trainee Psychology Teachers. Asian Social Science: 184-194. Vol. 10, No. 12. ISSN 1911-2017. E-ISSN 1911-2025. doi.org/10.5539/ass.v10n12p184.

(Poulcheria, Argyris, Zagkos, Ziontaki and Prokopis [2015]) Poulcheria Douna, Argyris Kyridis, Christos Zagkos, Zoi Ziontaki, and Prokopis Pandis. 2015. The Ideal University Teacher according to the Views of Greek Students. International Journal of Higher Education :145-158. Vol. 4, No. 2. https://doi.org/10.5430/ijhe.v4n2p145.

(Rusu, Șoitu, and Panaite [2011]) Rusu Carmen, Șoitu Laurențiu, and Panaite Oana. 2011. The ideal teacher. Theoretical and investigative. Procedia - Social and Behavioral Sciences:1017 - 1021. Vol 33. doi.org/10.1016/j.sbspro.2012.01.276.

(Schwartz and Holloway [2012]) Schwartz Harriet L., and Holloway Elizabeth L.. 2012. Partners in Learning: A Grounded Theory Study of Relational Practice between Master's Students and Professors. Mentoring and Tutoring: Partnership in Learning : 115-135. Vol. 20. Issue 1. doi.org/10.1080/13611267.2012.655454.

(Stan [2006]) Stan Eugen .2006. Managementul clasei. Bucureşti: Editura Aramis, 58-78.

(Sterling [2010]) Sterling Stephen. 2010. Learning for resilience, or the resilient learner? Towards a necessary reconciliation in a paradigm of sustainable education. Environmental Education Research: 511-528. Vol. 16. Issue 5-6. doi.org/10.1080/13504622.2010.505427

(Surdu [2000]) Surdu Emil. 2000. Fenomenul educațional. Timișoara: Editura Mirton, p. 110.

(Umbach, and Warwrzynski [2005]) Umbach Paul. D., and Warwrzynski Matthew R. 2005. Faculty Do Matter: The Role of College Faculty in Student Learning and Engagement. Research in Higher Education: 153-184. Vol 46. Issue 2. doi: 10.1007/s11162-004-1598-1.

(Vinaden [2015]) Vianden Jörg 2015. What Matters in College to Students: Critical Incidents in the Undergraduate Experience. Journal of Student Affairs Research and Practice: 287-299. Vol 52. Issue 3.. https://doi.org/10.1080/19496591.2015.1067226.

(Voicu and Ciolan [2008]) Voicu Octavian, and Ciolan Lucian. 2008. Opiniile și percepțiile profesorilor. Raport de cercetare al proiectului "S, Scoala așa cum este". Proiect UNICEF. Centrul Educația 2000+.

(Watts and Robertson [2011]) Watts J., and Robertson N. 2011. Burnout in University Teaching Staff: A Systematic Literature Review. Educational Research: 33-50. Vol.53. Issue 1. doi.org/10.1080/00131881.2011.552235. 
(Wolff, Sjöblom, Hofman-Bergholm, and Palmberg [2017]) Wolff Lili-Ann, Sjöblom Pia, HofmanBergholm Maria, and Palmberg Irmeli. 2017. High Performance Education Fails in Sustainability? A Reflection on Finnish Primary Teacher Education. Education sciences.Vol. 7. Issue 1. doi.org/10.3390/educsci7010032.

(Woods [2010]) Woods Charlotte. 2010. Employee Wellbeing in the Higher Education Workplace: A Role for Emotion Scholarship. Higher Education: 171-185. Vol. 60. Issue 2. doi:10.1007/s10734-0099293-y.

(Zepche and Leach [2010]) Zepke Nick, and Leach Linda. 2010. Beyond Hard Outcomes: 'Soft' Outcomes and Engagement as Student Success. Teaching In Higher Education : 661-673. Vol. 15. Issue 6.doi.org/10.1080/13562517.2010.522084. 